Bangladesh J. Plant Taxon. 20(1): 85-94, 2013 (June)

(C) 2013 Bangladesh Association of Plant Taxonomists

\title{
FOLIAR TRICHOMES OF CROTON L. (EUPHORBIACEAE: CROTONOIDEAE) FROM CHINA AND ITS TAXONOMIC IMPLICATIONS
}

\author{
Huan-Fang Liu ${ }^{1}$, Yun-Fei Deng and Jing-Ping Liao \\ Key Laboratory of Plant Resources Conservation and Sustainable Utilization, \\ Chinese Academy of Sciences, CN-510650 Guangzhou, PR China.
}

Keywords: Croton; Foliar trichome; Taxonomy; Infrageneric classification.

\begin{abstract}
Foliar trichomes of 21 species of the genus Croton L. from China have been examined using stereomicroscopy and scanning electron microscopy. Five trichome types characterized by their morphology are identified, viz., stellate, lepidote, simple, dendritic and appressed-rosulate. Only stellate trichome is observed in most species, with only six species that are found to maintain two or three trichome types. Trichome types and density are useful for species identification and sectional classification for Chinese species. Based on the trichome types and other morphological characters, 21 Chinese species are proposed to be placed in five sections. Croton crassifolius belongs to sect. Andrichnia; C. cascarilloides belongs to sect. Monguia; C. mangelong, C. kongensis, $C$. laevigatus and C. laniflorus belong to sect. Argyrocroton; C. lauioides, C. howii and C. damayeshu belong to sect. Adenophylli. The remaining Chinese Croton species might be placed into sect. Croton. A key for Chinese Croton species based on trichome morphology is provided.
\end{abstract}

\section{Introduction}

Croton L. (Euphorbiaceae s.s.) is one of the largest genera of flowering plants, with about 1300 species of herbs, shrubs, trees and occasionally lianas that are ecologically prominent and important elements of secondary vegetation in the tropical and subtropical regions worldwide (Webster, 1993; Radcliffe-Smith, 2001). Croton belongs to subfamily Crotonoideae (APG, 2009; Wurdack and Davis, 2009), is characterized by mostly lactiferous taxa having pollen with an unusual (crotonoid) exine pattern of triangular supratectal elements attached to a network of muri with short columellae (Nowicke, 1994). The synapomorphy that characterizes Croton is the inflexed conformation of the tips of the staminal filaments in bud, which causes the anthers to be introrsely inverted until anthesis (Berry et al., 2005).

Because of the large number of species and extensive morphological variation, it has been proved difficult to define and delimit sections and subsections within the genus Croton (Webster et al., 1996) despite the efforts of many taxonomists (Pax and Hoffmann, 1931; Webster, 1993). Webster (1993) established the most recent infrageneric classification, recognizing 40 sections in the genus mainly based on the New World taxa. Among them, three were reassigned generic status by Radcliffe-Smith (2001). Webster (1993) pointed out that his treatment of Old World taxa was much more cursory than that of New World taxa because of lack of familiarity with the living plants in Africa, Madagascar and Asia. Berry et al. (2005) presented a molecular systematic analysis of the genus Croton and tribe Crotoneae using nrITS and $t r n L-t r n F$ DNA sequences data to test the validity of Webster's classification. van Ee et al. (2011) revised the infrageneric classification and proposed a new system for New World Croton dividing into four subgenera and 31 sections including some species described as new ones.

\footnotetext{
${ }^{1}$ Corresponding author. Email: hfliu@scbg.ac.cn
} 
Trichomes have played an important role in plant taxonomy at generic, infragenetic and specific levels (Hardin, 1979; Theobald et al., 1979) in groups of wide taxonomic range, such as Cuphea P. Browne (Lythraceae: Amarasinghe et al., 1991), Stachys L. (Lamiaceae: Salmaki et al., 2009) and Chelonopsis Miquel (Lamiaceae: Xiang et al., 2010).

One of the most significant characters for infrageneric classification of Croton is the trichome morphology. Previous studies showed that trichome types have great variation within Croton (Webster et al. 1996; de Sá-Haiad et al., 2009; Senakun and Chantaranothai, 2010). Müller (1866) characterized the taxa as having stellate and lepidote hairs. Solereder (1908) and Metcalfe and Chalk (1950) noted that stellate and lepidote hairs also occur in other genera of subfamily Crotonoideae. Webster et al. (1996) identified foliar trichome characteristics for 120 species from 36 sections in Croton and established the possible evolutionary relationships among the different sections based on trichome characters. Senakun and Chantaranothai (2010) observed 23 Thai species and recognized seven trichome types.

In China, 23 species of Croton are recorded, including 15 endemic species (Li and Esser, 2008). Among them, only five species are placed in the 40 sections of Webster (1993). Moreover, foliar trichomes in Croton from China are not well-studied. Chang (1996) and Li and Esser (2008) described two main trichome types in Chinese Croton species, peltate scales [same as lepidote of Webster et al. (1996)] and stellate. Previously, foliar trichomes of only seven Chinese Croton species have been observed (Webster, 1993; Senakun and Chantaranothai, 2010). In the present work, we characterize the foliar trichomes of young to mature leaves of 21 species from China, including 15 endemic species. The objectives of this study are to provide descriptions, illustrations, and a survey of the trichomes in these 21 species using stereomicroscopy and scanning electron microscopy (SEM) and to propose the infrageneric classification for Chinese species.

\section{Materials and Methods}

Leaf samples of 21 species of Croton were obtained from dry specimens deposited at the herbarium of South China Botanical Garden, Chinese Academy of Sciences (IBSC). Both young and mature leaves were observed for each species. Two to four samples were examined for each species. A list of investigated materials is given in Table 1. Density of foliar trichomes was observed under Zeiss Stemi SV 11 stereomicroscopy, and photographed with an AxioCam MRC digital camera.

Both young and mature leaves were washed in 95\% ethanol. Whole sections of young leaves and $0.5 \times 0.5 \mathrm{~cm}$ of mature leaf fragments were bisected and mounted on copper stubs so that both adaxial and abaxial surfaces faced upwards. The mounts were air-dried, and coated with gold in a JFC-1600 sputter coater (JEOL Ltd, Tokyo, Japan). Observations and digital images were collected with a JEOL JSM-6360LV SEM (JEOL Ltd, Tokyo, Japan). The terminology follows Webster et al. (1996) and Senakun and Chantaranothai (2010).

\section{Results}

The main types of the trichomes and their density among the Croton species studied are summarized in Table 2. Selected SEM micrographs of trichome types are presented in Figure 1. Foliar trichomes of 21 Chinese Croton can be separated into five types; stellate, lepidote, simple, dendritic and appressed-rosulate. Glandular trichomes are not observed.

Type I. Stellate trichome. This trichome type is characterized by its star-shaped form in one plane that is usually flattened onto the lamina with 0-30\% webbing (Webster et al., 1996; Senakun and Chantaranothai, 2010). Two subtypes are observed. Subtype Ia, appressed-stellate (radii webbed 0-15\%), with porrect radius, occurs in C. dinghuensis H.S. Kiu, C. euryphyllus W.W. Sm., 
C. lachnocarpus Benth. (Fig. 1A), C. merrillianus Croizat, C. tiglium L., C. yunnanensis W.W. Sm., C. chunianus Croizat (Fig. 1B), C. cnidophyllus Radcl.-Sm. \& Govaerts (Fig. 1C), C. yanhuii Y.T. Chang (Fig. 1D) and C. crassifolius Geiseler (Fig. 1E). Subtype Ib, stellate or stellate-rotate (radii webbed 15-30\%) occurs in C. lauioides Radcl.-Sm. \& Govaerts (Fig. 1F), stellate with porrect radius trichome which occurs in C. howii Merr. \& Chun ex Y.T. Chang (Fig. 1G), and stellate trichome sometimes with porrect radius occurs in C. damayeshu Y.T. Chang (Fig. 1H).

Table 1. List of Croton species used in the present study.

\begin{tabular}{|c|c|c|c|}
\hline Species & Section & Locality & Voucher \\
\hline 1. Croton cascarilloides Raeusch. & Monguia & Guangxi & X. W. Gao 55292 \\
\hline 2. ${ }^{*}$ C. chunianus Croizat & Croton & Hainan & K. Z. Hou 71927 \\
\hline 3. ${ }^{*}$ C. cnidophyllus Radcl.-Sm. \& Govaerts & Croton & Yunnan & Menglian Expedition 9214 \\
\hline 4. C. crassifolius Geiseler & Andrichnia & Guangdong & H. G. Ye 7742 \\
\hline 5. *C. damayeshu Y. T. Chang & Adenophylli & Yunnan & H. T. Tsai 5003 \\
\hline 6. ${ }^{*}$ C. dinghuensis H. S. Kiu & Croton & Guangdong & S. T. Lin 30475 \\
\hline 7. *C. euryphyllus W.W.Sm. & Croton & Guangdong & H. S. Kiu 571 \\
\hline 8. *C. hancei Benth. & Croton & Guangxi & C. L. Tso 23429 \\
\hline 9. *C. howii Merr. \& Chun ex Y. T. Chang & Adenophylli & Hainan & L. Tang 3303 \\
\hline 10. C. kongensis Gagnep. & Argyrocroton & Hainan & Z. X. Li \& F. W. Xing 1036 \\
\hline 11. C. lachnocarpus Benth. & Croton & Guangdong & B. Y. Chen 2036 \\
\hline 12. ${ }^{*}$ C. laevigatus Vahl & Argyrocroton & Hainan & K. Z. Hou 73784 \\
\hline 13. C. laniflorus Geiseler & Argyrocroton & Hainan & S. H. Chun 11196 \\
\hline 14. *C. laui Merr. \& F. P. Metcalf & Croton & Hainan & Z. X. Li 2540 \\
\hline 15. *C. lauioides Radcl.-Sm. \& Govaerts & Adenophylli & Hainan & C. Wang 34386 \\
\hline 16. *C. mangelong Y.T. Chang & Argyrocroton & Yunnan & K. M. Feng 20258 \\
\hline 17. ${ }^{*}$ C. merrillianus Croizat & Croton & Hainan & C. L. Tso 43813 \\
\hline 18. ${ }^{*}$ C. purpurascens Y.T. Chang & Croton & Guangdong & H. S. Kiu 562 \\
\hline 19. C. tiglium L. & Croton & Guangxi & Z. S. Chung 808393 \\
\hline 20. *C. yanhuii Y.T. Chang & Croton & Yunnan & W. Z. Li 85725 \\
\hline 21. *C. yunnanensis W.W. Sm. & Croton & Yunnan & $\begin{array}{l}\text { Department of Biology, } \\
\text { Yunnan University } 757\end{array}$ \\
\hline
\end{tabular}

*Species endemic to China.

Type II. Lepidote trichome. The individual lepidote hair resembles an appressed-stellate hair but has radii that are connected by webbing so that the trichome forms a more or less shield-like scale (Webster et al., 1996). In our study, this type includes three subtypes. Subtype IIa, stellate-lepidote (radii webbed 30-50\%), sometimes with porrect radius, occurs in C. laevigatus Vahl (Fig. 1I) and C. laniflorus Geiseler. Subtype IIb, dentate-lepidote (radii webbed 50-80\%), sometimes with porrect radius, occurs on the adaxial surface of $C$. cascarilloides Raeusch. (Fig. 1J). Subtype IIc, lepidote-subentire (radii webbed 80-100\%) occurs in C. kongensis Gagnep., C. mangelong Y.T. Chang and the abaxial surface of $C$. cascarilloides (Fig. 1K).

Type III. Simple trichome. This type is stiffly erect, directed upward from an inclined base (Payne, 1978). This type is only found in C. crassifolius (Fig. 1E). 


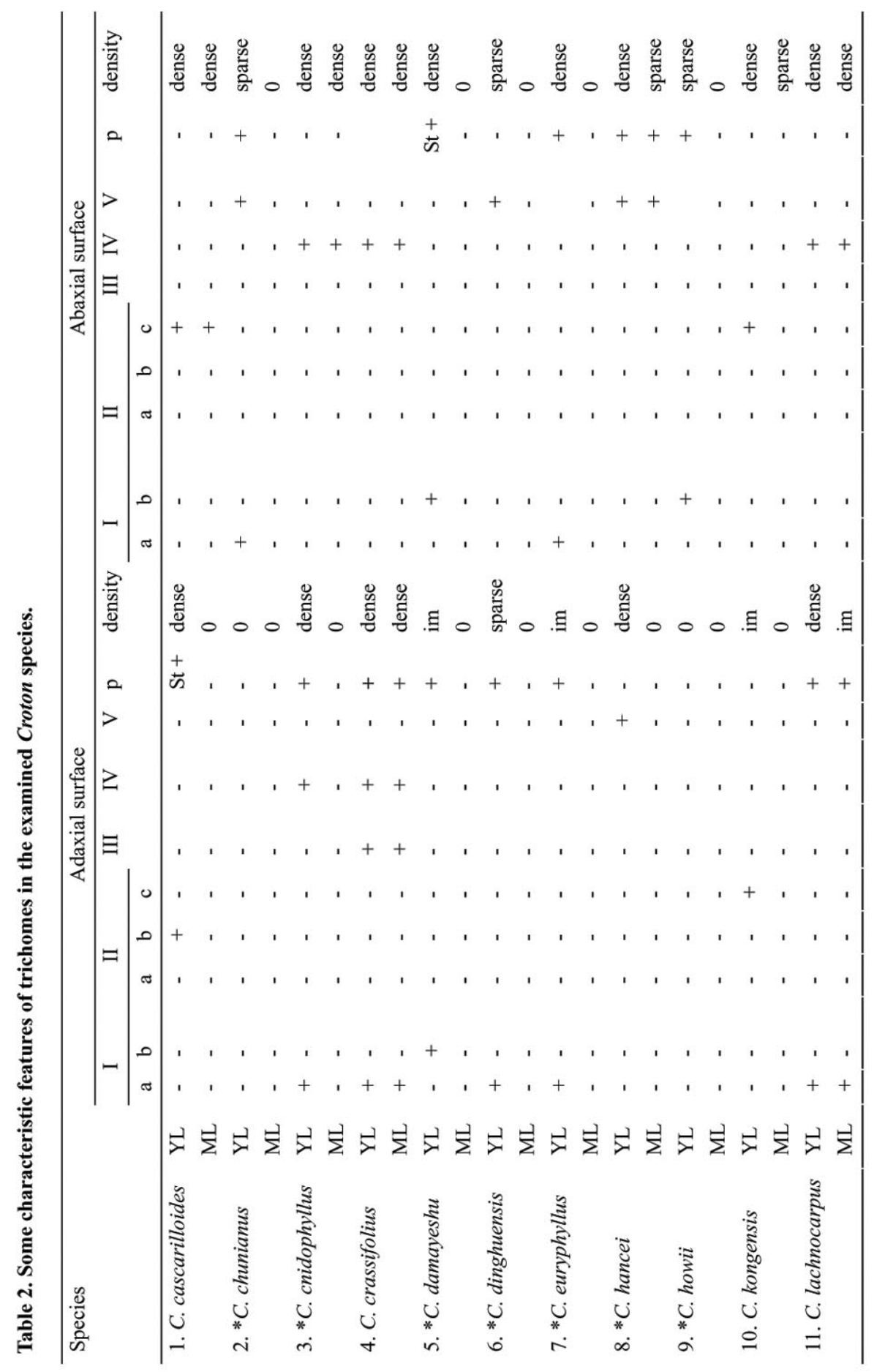




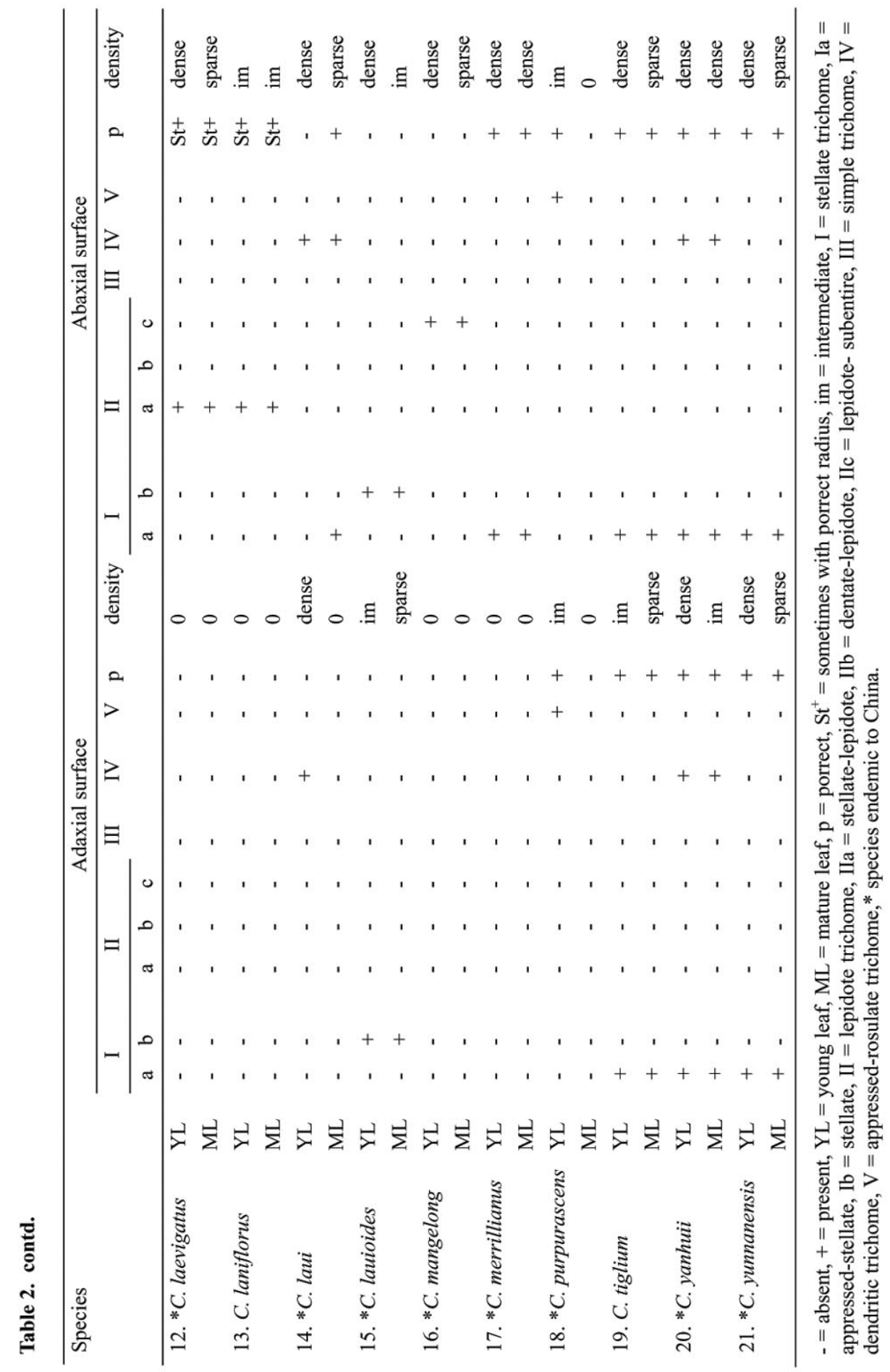



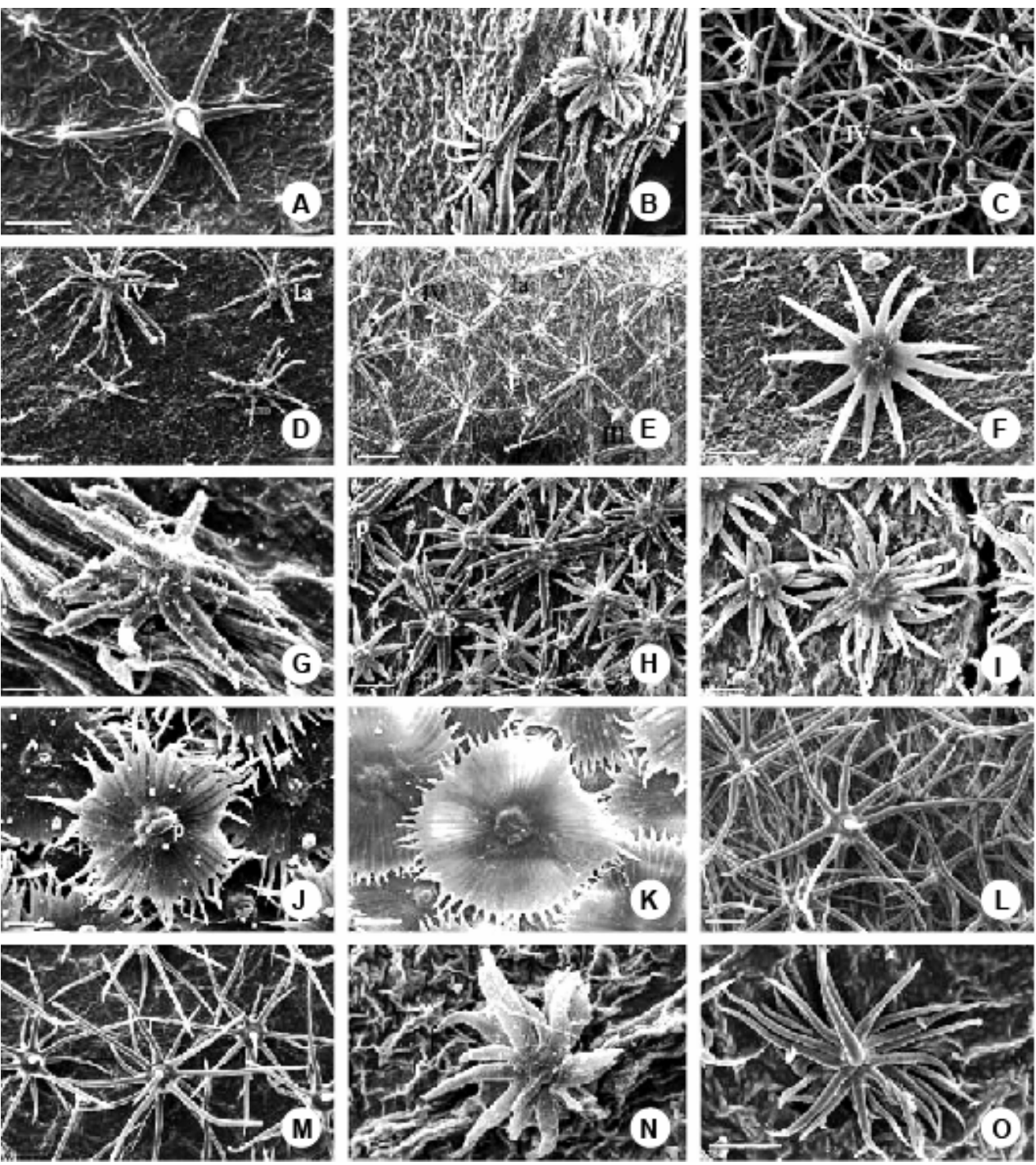

Fig. 1. SEM micrographs of trichomes in Croton: (A) Appressed-stellate with porrect radius trichome in C. lachnocarpus on Adm; (B) Appressed-stellate with porrect radius (Ia) and appressed-rosulate (V) trichomes in C. chunianus on Aby; (C) Appressed-stellate with porrect radius (Ia) and dendritic (IV) trichomes in C. cnidophyllus on Adm; (D) Appressed-stellate with porrect radius (Ia) and dendritic (IV) trichomes in C. yanhuii on Adm; (E) Appressed-stellate with porrect radius (Ia), simple (III) and dendritic (IV) trichomes in C. crassifolius on Abm; (F) Stellate trichome in C. lauioides on Ady; (G) Stellate with porrect trichome in C. howii on Aby; $(\mathrm{H})$ Stellate with sometimes porrect radius (p) trichome in C. damayeshu on Aby; (I) Stellate-lepidote with sometimes porrect radius (p) trichome in C. laevigatus on Aby; (J) Dentate-lepidote with sometimes porrect radius (p) trichome in C. cascarilloides on Ady; (K) Lepidote-subentire trichome in C. cascarilloides on Abm; (L) Dendritic trichome in C. crassifolius on Abm; (M) Dendritic trichome in C. lachnocarpus on Abm; (N) Appressed-rosulate trichome in C. dinghuensis on Aby; (O) Appressed-rosulate with porrect trichome in C. purpurascens on Ady. Abm = the abaxial surface of mature leaf; Aby = the abaxial surface of young leaf; Adm = the adaxial surface of mature leaf; Ady = the adaxial surface of young leaf. Scale bars $=200 \mu \mathrm{m}$ (E), $100 \mu \mathrm{m}$ (A-D, H, J-K, L-M, O), $50 \mu \mathrm{m}$ (F-G, I, N). 
Type IV. Dendritic trichome. This type has the radii inserted at different levels on an axis (Webster et al., 1996). Dendritic trichome with porrect radius occurs in C. cnidophyllus, C. crassifolius (Figs 1E, L), C. lachnocarpus (Fig. 1M), C. laui Merr. \& F.P. Metcalf and C. yanhuii (Fig. 1D).

Type V. Appressed-rosulate trichome. This type resembles stellate ones, but differs in the larger number of radii that are not all in a single whorl (Webster et al., 1996). This type includes appressed-rosulate and appressed-rosulate with porrect radius. Appressed-rosulate trichome occurs in C. dinghuensis (Fig. 1N) and C. hancei Benth. Appressed-rosulate trichome with porrect radius occurs in C. chunianus (Fig. 1B), C. hancei and C. purpurascens Y.T. Chang (Fig. 1O).

Density of trichome distribution is variable on different surfaces even within the same species. In general, trichomes are much denser on the abaxial surface than on the adaxial surface. Among 21 observed species, six species are glabrous on the adaxial surface even when they are at very young stage: C. chunianus, C. howii, C. laevigatus, C. laniflorus, C. mangelong and $C$. merrillianus. The density of trichomes decreases drastically with leaf development on both surfaces of $C$. yunnanensis and on the abaxial surface of $C$. hancei, C. kongensis, C. laevigatus, $C$. laui, C. mangelong and C. tiglium.

In some species, trichomes are observed on both surfaces when young, but fall off completely on either both surfaces or on a single surface when mature. For example, trichomes fall off completely on both surfaces in C. damayeshu, C. dinghuensis, C. euryphyllus and C. purpurascens, or on the adaxial surface in C. cascarilloides, C. cnidophyllus, C. hancei, C. kongensis and C. laui, or on the adaxial surface in $C$. chunianus and $C$. howii.

Variation in trichome type can be used to differentiate the Croton species examined in this study. In most species, only stellate trichome is observed. Only six species are found to have two or three trichome types. In $C$. chunianus, a few appressed-rosulate and few appressed-stellate with porrect radius trichomes are observed on the abaxial surface (Fig. 1B) and its adaxial surface is glabrous even very young. In C. cnidophyllus, a few dendritic and few appressed-stellate trichomes occur on the adaxial surface (Fig. 1C), and only dendritic trichome occurs on the abaxial surface. In C. crassifolius, three types of trichomes (appressed-stellate with porrect radius, simple and dendritic) are observed on the adaxial leaf surface (Fig. 1E), and only dendritic trichome occurs on the abaxial surface (Fig. 1L). This species can also be easily distinguished from other Chinese Croton species by possessing simple trichome which is not found in any other species. In C. dinghuensis, appressed-stellate with porrect radius trichome is found on the adaxial surface and appressed-rosulate trichome is observed on the abaxial surface (Fig. 1N). In $C$. lachnocarpus, it is observed that appressed-stellate with porrect radius trichome occurs on the adaxial surface (Fig. 1A) and dendritic trichome occurs on the abaxial surface (Fig. 1M). The dendritic with porrect radius trichome type and few appressed-stellate with porrect radius trichomes are found in C. yanhuii (Fig. 1D). In addition, two subtypes of trichomes are found in $C$. cascarilloides; dentate-lepidote trichome sometimes with porrect radius occurs on the adaxial surface (Fig. 1J), and leptidote-subentire trichome occurs on the abaxial surface (Fig. 1K).

\section{Discussion}

Among the 21 species we observed, seven species were also observed earlier by Webster et al. (1996) and Senakun and Chantaranothai (2010). Compared to their works, trichomes of $C$. lachnocarpus, C. laevigatus and C. tiglium are characterized as identical to their observation. Webster (1993) reported that $C$. kongensis had stellate trichome and was accordingly placed into Sect. Cascarilla, but we observed the lepidote-subentire trichome type as observed by Senakun and Chantaranothai (2010) based on Thai material. We cannot discuss more about the differences 
of the observation between our studies and Webster (1993), because we did not see the material observed by them. Only lepidote-subentire trichome was observed in C. cascarilloides by Senakun and Chantaranothai (2010), but we find that dentate-lepidote trichome sometimes with porrect radius occurs on the adaxial surface and lepidote-subentire trichome occurs on the abaxial surface. Senakun and Chantaranothai (2010) observed three types of trichomes (fasciculate, dendritic and glandular) in C. crassifolius, but we find that appressed-stellate with porrect radius, simple, and dendritic trichomes occur on the adaxial surface, and dendritic trichome occurs on the abaxial surface. Our observation accords with the previous studies (Webster et al., 1996; Chayamarit and van Welzen, 2005; Li and Esser, 2008). We could not check their voucher specimen of $C$. crassifolius observed by Senakun and Chantaranothai (2010) and therefore presume that their material was misidentified. Webster et al. (1996) indicated that the number and length of radii of trichomes could vary considerably on different leaves of a single specimen. It is supported by our observation. It also showed that the number and length of radii vary considerably even on same leaf of a single specimen. For example, it has 6-17 radii, 0.18-1.1 mm in diam. in C. yanhuii (Fig. 1D).

The foliar trichome is one of the most important characters to define sections in the genus Croton (Webster, 1993). According to the trichome types and other morphological characters, Chinese Croton species can be divided into five sections. Two species, C. cascarilloides and $C$. crassifolius, have multifid styles. They can be easily distinguished from each other by foliar trichome type. Webster (1993) placed C. crassifolius into sect. Croton, which had lepidote trichome. However, C. crassifolius has stellate trichome and it might be a member of sect. Andrichnia. Webster (1993) uncertainly listed C. cascarilloides under both sect. Anisophyllum, having appressed-stellate trichome, and sect. Monguia, having lepidote trichome. This is the same as Senakun and Chantaranothai (2010) observed, C. cascarilloides has lepidote trichome and it is suggested to be placed in sect. Monguia. Among species with bifid styles, C. mangelong, $C$. kongensis, C. laevigatus and C. laniflorus are different from other Chinese species in having lepidote trichome and belong to sect. Argyrocroton which is characterized by the bifid style and lepidote trichomes. Croton laevigatus and C. laniflorus were placed by Müller (1866) in sect. Decapetalon, however, they are not related to the species of sect. Decapetalon because they have glands on the leaf blades while eglandular in sect. Decapetalon. Croton lauioides, C. howii and C. damayeshu have stellate trichome and belong to sect. Adenophylli. Croton hancei and C. purpurascens with appressed-rosulate trichomes and the remaining Chinese Croton species having appressed-stellate trichomes might be placed into sect. Tiglium according to the classification of Webster (1993). However, the correct name for sect. Tiglium is sect. Croton because the section including C. tiglium, the type of the genus. Although Webster et al. (1996) superseded Small's (1913) choice of $C$. tiglium as the lectotype of Croton and designated C. aromaticus L., the valid lectotype of the genus is C. tiglium (Britton, 1918; van Ee and Berry, 2010).

A key to species of Croton from China is provided as follows.

1. With simple trichome

C. crassifolius

1. Without simple trichome

2. With dentritic trichome

3. Only dentritic trichome

C. laui

3. With dentritic and appressed-stellate trichome

4. Dentritic trichome only on abaxial surface

C. lachnocarpus

4. Dentritic trichome on both surfaces

5. Without appressed-stellate trichome on abaxial surface

5. With appressed-stellate trichome on abaxial surface

C. cnidophyllus

C. yanhuii 
2. Without dentritic trichome

6. With lepidote trichome

7. With dentate-lepidote trichome

C. cascarilloides

7. Without dentate-lepidote trichome

8. With lepidote-subentire trichome

9. With lepidote-subentire trichome on the adaxial surface

9. Without lepidote-subentire trichome on the adaxial surface

C. kongensis

8. Without lepidote-subentire trichome

10. Stellate-lepidote trichome is intermediate when mature

10. Stellate-lepidote trichome is sparse when mature

C. mangelong

C. laniflorus

C. laevigatus

6. Without lepidote trichome

11. Glabrous on adaxial surface

12. With appressed-rosulate trichome

C. chunianus

12. Without appressed-rosulate trichome

13. With stellate trichome

13. Without stellate-trichome

C. howii

C. merrillianus

11. With trichome on adaxial surface

14. With appressed-rosulate trichome

15. Only appressed-rosulate trichome

16. All trichome fallen down when mature

C. purpurascens

16. Trichome not fallen down when mature

C. hancei

15. With appressed-rosulate and appressed-stellate trichome

C. dinghuensis

14. Without appressed-rosulate

17. With stellate trichome

18. All trichome fallen down when mature

18. Trichome not fallen down when mature

C. damayeshu

C. lauioides

17. Without stellate trichome

19. All trichome fallen down when mature

C. euryphyllus

19. Trichome not fallen down when mature

20. Trichome is dense on adaxial surface when young

C. yunnanensis

20. Trichome is intermediate on adaxial surface when young

C. tiglium

\section{Acknowledgements}

This work was supported by the National Natural Science Foundation of China (31200246, 31100240, 31200176), South China Botanical Garden-Shanghai Institute of Plant Physiology \& Ecology Joint Fund and the Foundation of Key Laboratory of Plant Resources Conservation and Sustainable Utilization, South China Botanical Garden, Chinese Academy of Sciences. We thank the curator of the herbarium, South China Botanical Garden, Chinese Academy of Sciences (IBSC) for his permission to access their collections. We also thank Dr. Chelsea Specht and Dr. Yuping Lin working in University of California, Berkeley for their English revision.

\section{References}

Amarasinghe, V., Graham, S.A. and Graham, A. 1991. Trichome morphology in the genus Cuphea (Lythraceae). Bot. Gaz. 152: 77-90.

APG (Angiosperm Phylogeny Group). 2009. An update of the Angiosperm Phylogeny Group classification for the orders and families of flowering plants: APG III. Bot. J. Linn. Soc. 161: 105-121.

Berry, P.E., Hipp, A.L., Wurdack, K.J., Ee, B.V. and Riina, R. 2005. Molecular phylogenetics of the giant genus Croton and tribe Crotoneae (Euphorbiaceae sensu stricto) using ITS and trnL-trnF DNA sequence data. Am. J. Bot. 92: 1520-1534. 
Britton, N.L. 1918. Flora of Bermuda. Charles Scribner’s Sons, New York.

Chang, Y.T. 1996. Croton. In: Kiu, H.S. (Ed.), Flora Reipublicae Popularis Sinicae, Vol. 44, No. 2. Science Press, Beijing.

Chayamarit, K. and van Welzen, P.C. 2005. Croton. In: Santisuk, T. and Larsen, K. (Eds), Flora of Thailand. Vol. 8, No. 1. The Forest Herbarium, National Park, Wildlife and Plant Conservation Department, Bangkok, pp. 189-226.

de Sá-Haiad, B., Serpa-Ribeiro, A.C.C., Barbosa, C.N., Pizzini, D., de O. Leal D., de Senna-Valle L., de Santiago-Fernandes, L.D.R. 2009. Leaf structure of species from three closely related genera from tribe Crotoneae Dumort. (Euphorbiaceae s.s., Malpighiales). Plant Syst. Evol. 283: 179-202.

Hardin, J.W. 1979. Patterns of variation in foliar trichomes of eastern North American Quercus. Am. J. Bot. 6(5): 576-585.

Li, B.T. and Esser, H. 2008. Croton. In: Wu, Z.Y., Raven, P.H. and Hong, D.Y. (Eds), Flora of China, Vol. 11. Science Press, Beijing \& Missouri Botanical Garden Press, St. Louis, pp. 258-264.

Metcalfe, C.R. and Chalk, L. 1950. Anatomy of the Dicotyledons, Vol. 2. Clarendon Press, Oxford, pp. 1207-1235.

Müller, J. 1866. Croton. In: de Candolle, A.P. (Ed.), Prodromus Systematis Naturalis Regni Vegetabilis 15(2). Paris, Strasbourg \& London.

Nowicke, J.W. 1994. A palynological study of Crotonoideae (Euphorbiaceae). Ann. Mo. Bot. Gard. 81: 245-269.

Pax, F. and Hoffmann, K. 1931. Euphorbiaceae, Crotoneae. In: Engler, A. and Prantl, K. (Eds), Die Natürlichen Pflazmfamiliem, ed. 2, 19c: Leipzig: Wilhelm Engelmann, pp. 83-88.

Payne, W.W. 1978. A glossary of plant hair terminology. Brittonia 30: 239-255.

Radcliffe-Smith, A. 2001. Genera Euphorbiacearum. Royal Botanic Gardens, Kew.

Salmaki, Y., Zarre, S., Jamzad, Z. and Bräuchler, C. 2009. Trichome micromorphology of Iranian Stachys (Lamiaceae) with emphasis on its systematic implication. Flora 204: 371-381.

Senakun, C. and Chantaranothai, P. 2010. A morphological survey of foliar trichomes of Croton L. (Euphorbiaceae) in Thailand. Thai. For. Bull. (Bot.) 38: 167-172.

Small, J.K. 1913. Croton. In: Britton, N.L. and Brown, A. (Eds), An illustrated flora of the Northern United States, ed. 2, Vol. 2. New York: Charles Scribner's Sons, pp. 454-455.

Solereder, H. 1908. Euphorbiaceae. In: Systematic Anatomy of the Dicotyledons, Vol. 2. Oxford University Press, Oxford. pp. 739-763.

Theobald, W.L., Krahulik, J.L. and Rollins, R.C. 1979. Trichome description and classification. In: Metcalfe, C.R. and Chalk, L. (Eds), Anatomy of the Dicotyledons, 2nd edition. Clarendon Press, Oxford, pp. 40-53.

van Ee, B.W. and Berry, P.E. 2010. Typification notes for Croton (Euphorbiaceae). Harvard Papers in Botany 15: $73-84$.

van Ee, B.W., Riina, R and Berry, P.E. 2011. A revised infrageneric classification and molecular phylogeny of New World Croton (Euphorbiaceae). Taxon 60: 791-823.

Webster, G.L. 1993. A provisional synopsis of the sections of the genus Croton (Euphorbiaceae). Taxon 42: 793-823.

Webster, G.L., Del-arco-aguilar, M.J. and Smith, B.A. 1996. Systematic distribution of foliar trichome types in Croton (Euphorbiaceae). Bot. J. Linn. Soc. 121: 41-57.

Wurdack, K.J. and Davis, C.C. 2009. Malpighiales phylogenetics: Gaining ground on one of the most recalcitrant clades in the angiosperm tree of life. Am. J. Bot. 96(8): 1551-1570.

Xiang, C.L., Dong, Z.H., Peng, H. and Liu, Z.W. 2010. Trichome micromorphology of the East Asiatic genus Chelonopsis (Lamiaceae) and its systematic implications. Flora 205: 434-441. 